\title{
REPORT OF THE SUB-COMMITTEE ON UTILIZATION
}

$\mathrm{D}$

URING the past year the Sub-Committee continued to concentrate upon the problem of the utilization of low-grade wood for fuel. In this study two separate courses were followed. First, an investigation of wood-burning stoves and furnaces was started, in co-operation with the Fuel Research Laboratories of the Bureau of Mines, with a view to determining the efficiencies of types of equipment now in common use both in Canada and abroad. The object of this study is, of course, to see if anything can be done to improve the method of burning wood by making it more economical and easier to use. Second, a survey was conducted in the Province of Quebec and Ontario to determine the present status of the fuelwood trade for the purpose of discovering what steps might be taken to improve it from the standpoint of better utilization.

Laboratory tests on wood-burning equipment were commenced in September at the Fuel Research Laboratories, and experiments are still in progress. In all, seven stoves will be tested for efficiency, namely, a Quebec heater, a box-type heater, and two varieties of circulating heaters-all Canadian made. The remaining three are European heaters of different patterns, but all designed on the slow-combustion principle. Two Swedish, woodburning, hot-water furnaces will also be tried out, probably in comparison with a Canadian hot-water furnace fitted with special wood-grates because no hot-water furnace designed especially for burning wood is made in Canada.

The testing of stoves is difficult and complicated since there is no practicable method of measuring radiant heat. Efficiencies must, therefore, be obtained through the careful measurement of heat losses which may be summarized as (1) losses through the escape of unburnt combustibles, (2) losses through the escape of gases at high temperatures, (3) losses due to the presence of moisture in the wood and (4) ash-pit losses. These losses having been determined and the total calorific value of the fuel fired being known, it is possible, by calculating the difference between these two amounts, to determine the useful heat out-put of the stove.

The efficiency of a stove, however, usually varies inversely as the rate of combustion at which it is operated, and hence it is necessary to run each stove at several stages in its range of combustion rates from the lowest to the highest. In any one test as even a rate of burning as possible must be maintained and consequently a number of separate tests on each stove 
are required. Each test lasts for a continuous period of 48 hours, and between three and six tests are run on each stove.

No definite comparative figures are yet available to show whether or not there is any marked improvement in efficiency of the foreign stoves over Canadian ones, but present indications, which are subject to revision, are that the former are not greatly superior.

The trials of furnaces have not yet been begun, but these will be a great deal easier to perform due to the fact that the efficiency may be determined by direct methods by measuring the heat transference from the fire to the heating medium which in this case is water.

In the second phase of the investigation about 125 fuel dealers in Quebec and Ontario were interviewed with the object of learning at first hand something of the present conditions in the fuelwood market in the various localities visited. The main features discussed were the adequacy of supplies, problems of transportation, price fluctuations, marketing methods and costs, consumers' requirements and objections, and the measurement of fuelwood.

It would be practically impossible to summarize all the findings on these points for the whole area covered because conditions vary so widely even in neighboring districts. In general it may be said that the use of fuelwood is far more extensive in Quebec than in Ontario and the prospects for increasing its use are probably better in the former Province than in the latter. This seems due in large measure to a genuine preference for wood fuel on the part of the French Canadian who will quite often pay higher relative prices for wood than for other fuels. Such a preference was nowhere apparent in Ontario.

Transportation is certainly a major problem in the marketing of fuelwood. As a general rule wood is carried by truck from the point of cutting to the market when the distance is not more than 50 to 80 miles. Wood is shipped by rail, however, distances upward of 300 miles, but such long hauls are made possible only through the very low prices asked for fuelwood in isolated districts--prices which very often would not cover the cost of reasonable wages alone. This fact would seem to indicate that a reduction in transportation costs would be of benefit in enlarging the areas from which fuelwood could profitably be drawn to the centres of consumption. Unfortunately it is not likely that this would be the case. A reduction in transportation costs might well tend to lower the retail price of fuelwood and therefore increase its use, but there is little indication that it would affect the present tendency to get supplies from the nearest sources of supply 
regardless of cutting practices. The increased use of fuelwood might therefore only tend to accelerate the rate of recession of supplies from the marketing centre, a result of which cannot be justified by any principle of forestry or wood utilization. In other words the only plan which will be really helpful from the standpoint of improved utilization is one which will prevent the continuous depletion of supplies in certain areas while others remain overstocked.

Since, in the main, the farmer's woodlot is the mainstay in the supply of fuelwood, and will probably remain so, it seems essential that, to be successful, any attempt to increase the use of fuelwood must be accompanied by a vigorous campaign to educate the farmer to operate his woodlot on a sustained yield basis. This would tend to fix the hauling radius and create a desirable degree of stability in marketing. No matter how marketing costs may be altered there is only one other factor besides the practice of forestry which will halt the recession of supplies and that is the attainment of the greatest possible economic hauling radius at which point the transportation of fuelwood virtually ceases. In certain localities this point has been practically reached already.

Apart from the matter of actual depletion which was evident in very many localities an undesirable degree of instability in the fuelwood market was apparent throughout practically the entire area covered by the survey. Prices in general, and retail prices in particular, are subject to wide fluctuations which seem quite out of keeping with the shifting price levels of other commodities. In one locality the price of wood per cord in 1933 had fallen to 40 per cent. or less of the 1929 price, and three years later it was back to about 65 per cent. of the 1929 figure. In not a few instances prices had on occasion been pushed far above corresponding prices for other fuels. All this, of course, has a most unfavourably influence upon the fuelwood market in general alternately booming and stifling it. For the most part this difficulty seems to be due to the fact that the market is supplied chiefly by small producers who have a very limited knowledge of market conditions. It is encouraging to see that a start has been made to correct this condition in some parts of Quebec where suppliers are organizing for the purpose of studying their market and are voluntarily establishing regional price levels to promote stability. This is certainly a move in the right direction, but it cannot be denied that greatest possible stability will only be achieved when the cutting as well as the pricing of fuelwood is placed on a sound footing.

The foregoing observations apply, of course, to the cutting of cordwood, 
mill waste in the form of slabs, edging, and other cuttings naturally not being subject to them. The results of the survey in Quebec and Ontario showed that slabs and edgings are quite easily disposed of within the economic hauling radius and in a good many cases dealers reported that they could sell them in greater quantities if they could be obtained at competitive prices. Practically all mill waste is transported by rail and the area of distribution is therefore governed, in the main, by railway freight rates. It may, perhaps, fairly be said that more can be achieved in the field of reducing waste in sawmilling than in attempting to find markets for that at present produced, although no doubt there is scope for improvement in both directions.

With regard to the use of sawdust as a domestic fuel not much progress has yet been made in Eastern Canada. As has already been said transportation costs impede the use of all forms of wood fuel to a considerable degree, but in the case of sawdust the restriction is even greater since the relationship between bulk and value is even more unfavourable. However, it should be possible to promote the use of sawdust as a domestic fuel in mill towns. The most serious difficulty now apparent is that sawdust produced in the sawmills of Eastern Canada tends to be too high in moisture content for satisfactory use. Therefore, a cheap and simple means of drying the sawdust must be sought.

The question of the utilization of logging waste for fuel has not yet been considered in detail, but it seems logical to presume that the prospects in this direction are less promising than in others and hence the latter should receive prior consideration.

While so far the survey of market conditions and possibilities for expanding the markets for fuelwood have been confined to the thickly populated areas in Quebec and Ontario it is intended to gather similar information on other areas through the co-operation of the members of the Sub-Committee. In this way it is believed that a comprehensive picture of the situation throughout Canada can be obtained from which it may be possible to formulate broad plans which will bring the greater use of wood for fuel into line with a policy of improved utilization and not merely greater utilization.

January 22nd, 1938.

T. A. McElhanney, Chairman; E. S. Fellows, Secretary.

\section{DISCUSSION}

The President stated that wood had been found more economical than coal in heating the buildings of the University of New Brunswick. Special 
wood-burning furnaces are being installed in private houses in Fredericton.

Mr. Marritt thought more publicity should be given to the comparison of wood with other fuels, worked out by the Forest Products Laboratory.

Replying to a question by Mr. Kilby, Mr. Fellows thought sawdust would not likely become an important fuel in Eastern Canada except possibly in mill towns. 